\title{
Progressive hemianopsia caused by intracranial enchondroma in Ollier disease
}

\section{Figure Intracranial enchondroma}
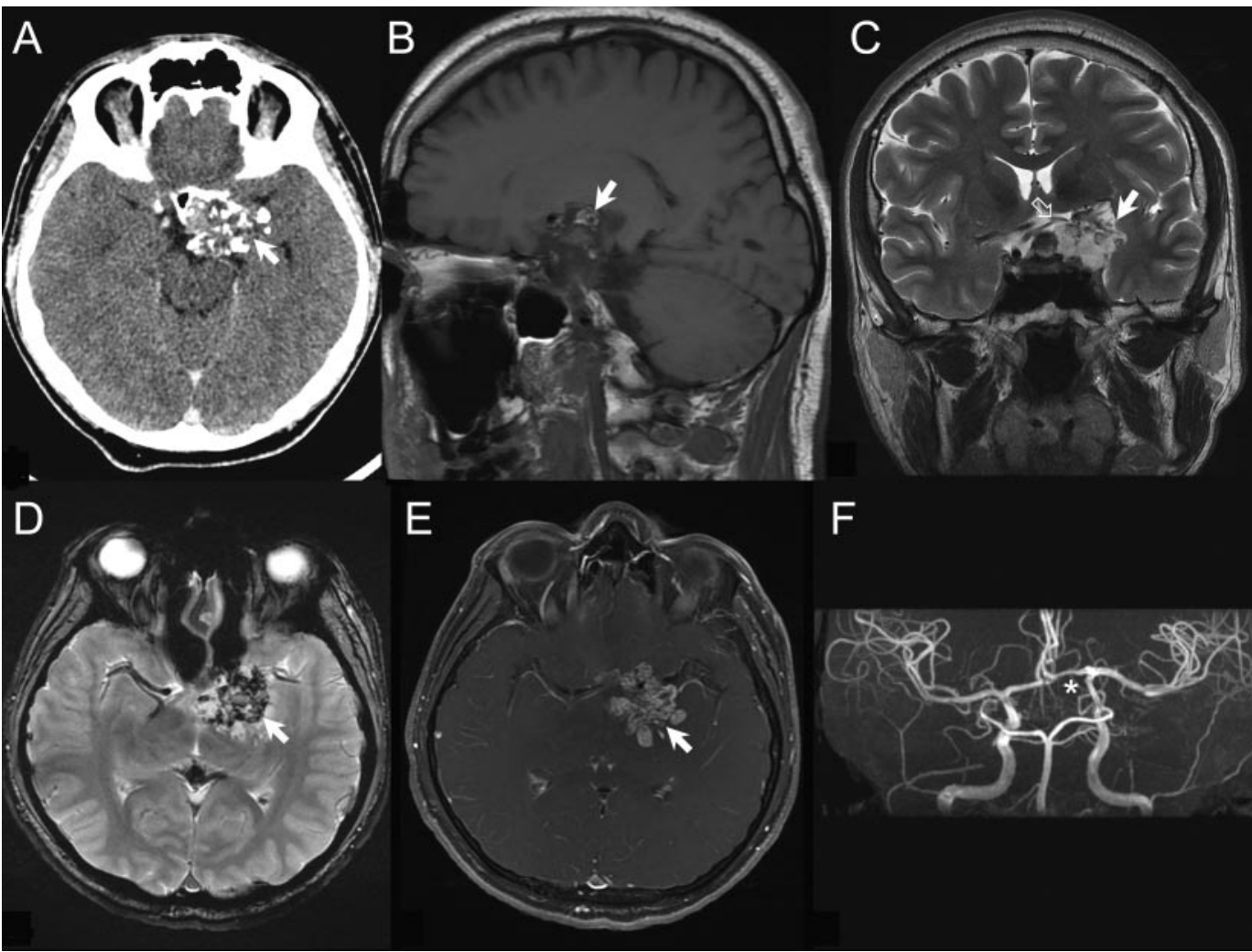

F

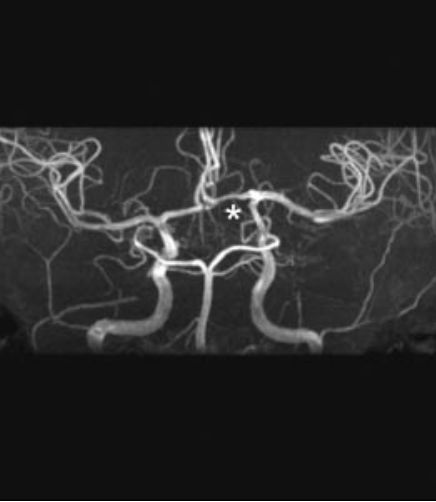

Large extra-axial tumor (arrow) from left clinoid demonstrates calcifications on CT (A), sagittal T1W (B), and transverse GRE (D) MRI, and chondroid matrix on coronal T2W (C) and transverse contrast-enhanced T1W (E) MRI. The tumor compresses optic chiasm ( $C$, open arrow) and distorts carotid termination on MR angiography ( $F$, asterisk).

A 31-year-old man with progressive right hemianopsia and Ollier disease (multiple enchondromatosis) underwent head CT and MRI (figure).

Images revealed a large tumor protruding from the left anterior clinoid process and impinging on the optic chiasm. Imaging features and clinical background were typical of an intracranial enchondroma. Surgery was deemed too risky considering the slow growth potential of the tumor and stability of symptoms.

Intracranial enchondroma is an uncommon tumor, usually solitary but occasionally associated with Ollier disease and Maffucci syndrome (multiple enchondromatosis and venous malformations). It appears similar to peripheral enchondromas with very few differential diagnoses (meningioma). Malignant degeneration is exceptional. ${ }^{1,2}$

T. Moser, MD, X.Z. Lin, MD, G. Bazille, MD, M. Fleury, MD, J.-L. Dietemann, MD, and S. Kremer, MD, PhD, Strasbourg, France

Disclosure: The authors report no disclosures.

Address correspondence and reprint requests to Dr. T. Moser, Service de Radiologie 2, Hôpital de Hautepierre, Avenue Molière, 67098 Strasbourg Cedex, France; thomas.moser@chru-strasbourg.fr

1. Brownlee RD, Sevick RJ, Rewcastle NB, Tranmer BI. Intracranial chondroma. AJNR Am J Neuroradiol 1997;18:889-893.

2. Sarwar M, Swischuk LE, Schecter MM. Intracranial chondromas. AJR Am J Roentgenol 1976;127:973-977. 


\section{Neurology}

\section{Progressive hemianopsia caused by intracranial enchondroma in Ollier disease}

T. Moser, X. Z. Lin, G. Bazille, et al. Neurology 2008;71;2018

DOI 10.1212/01.wnl.0000336976.07237.17

\section{This information is current as of December 8, 2008}

\section{Updated Information \& Services}

References

Subspecialty Collections

Permissions \& Licensing

Reprints including high resolution figures, can be found at: http://n.neurology.org/content/71/24/2018.full

This article cites 2 articles, 0 of which you can access for free at: http://n.neurology.org/content/71/24/2018.full\#ref-list-1

This article, along with others on similar topics, appears in the following collection(s):

All Oncology

http://n.neurology.org/cgi/collection/all_oncology

CT

http://n.neurology.org/cgi/collection/ct

MRI

http://n.neurology.org/cgi/collection/mri

Information about reproducing this article in parts (figures,tables) or in its entirety can be found online at:

http://www.neurology.org/about/about_the_journal\#permissions

Information about ordering reprints can be found online:

http://n.neurology.org/subscribers/advertise

Neurology ${ }^{\circledR}$ is the official journal of the American Academy of Neurology. Published continuously since 1951, it is now a weekly with 48 issues per year. Copyright . All rights reserved. Print ISSN: 0028-3878. Online ISSN: 1526-632X.

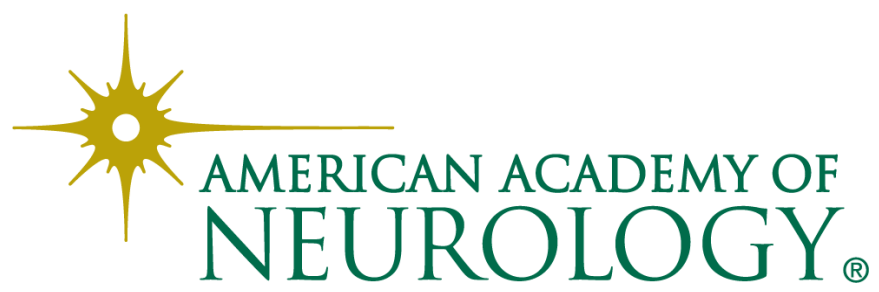

